ANTS OF NORTH AMERICA 



\section{ANTS OF NORTH AMERICA A Guide to the Genera}

\section{Brian L. Fisher and Stefan P. Cover}

Illustrated by Ginny Kirsch and Jennifer Kane Color images created by April Nobile

\section{甲}

UNIVERSITY OF CALIFORNIA PRESS Berkeley Los Angeles London 
University of California Press, one of the most distinguished university presses in the United States, enriches lives around the world by advancing scholarship in the humanities, social sciences, and natural sciences. Its activities are supported by the UC Press Foundation and by philanthropic contributions from individuals and institutions. For more information, visit www.ucpress.edu.

\section{University of California Press}

Berkeley and Los Angeles, California

University of California Press, Ltd.

London, England

(C) 2007 by the Regents of the University of California

Library of Congress Cataloging-in-Publication Data

Fisher, Brian L., 1964-

Ants of North America : a guide to the genera / Brian L. Fisher and Stefan P. Cover ; illustrated by Ginny Kirsch and Jennifer Kane; color images created by April Nobile.

p. cm.

Includes bibliographical references and index.

ISBN 978-0-520-25422-0 (pbk. : alk. paper)

1. Ants-United States-Identification. 2. Ants-Canada-Identification.

3. Ants-United States-Pictorial works. 4. Ants-Canada-Pictorial works.

I. Cover, Stefan P., 1952 - II. Title.

QL568.F7F48 2007

$595.79^{\prime} 6097-\mathrm{dc} 22$

Manufactured in China

$\begin{array}{llll}10 & 09 & 08 & 07\end{array}$

$\begin{array}{llllllllll}10 & 9 & 8 & 7 & 6 & 5 & 4 & 3 & 2 & 1\end{array}$

The paper used in this publication meets the minimum requirements of ANSI/NISO Z39.48-1992 (R 1997) (Permanence of Paper)

Cover: top, Cephalotes varians; row left to right, Pseudomyrmex gracilis, Pogonomyrmex badius, Atta mexicana, Camponotus ulcerosus, Acromyrmex versicolor, Labidus coecus. Photos by April Nobile. 
No living person has exerted a more profound or more beneficent impact on the science of ant systematics than Barry Bolton. During his career, he has been a pioneer, a leader, an exemplar, a mentor, and a friend to a whole generation of ant systematists. The quality of his work sets the standard for the entire field. Therefore, it is with the greatest pleasure that we dedicate this book to him in acknowledgment of his retirement from the Natural History Museum in London, England in 2004. 
